\title{
THE EFFECT OF LOOK-UP TECHNIQUE ON SPEAKING FLUENCY
}

\author{
Achlia Niza Ayunda \\ Universitas Kanjuruhan Malang \\ Achliabaehaqi26@yahoo.com
}

\begin{abstract}
This research is conducted to find an effective technique to teach speaking of second semester students. To collect the data, this research using pre- and post-test. The treatment is look-up technique in which the learners work in pairs facing each other. One is the reader, the other is the listener. The reader holds the book containing the dialogue at about chest level and slightly to the left. This enables the reader to look at the book and then look at the listener, moving only her eyes and not having to move her head at all. The reader looks at the book and tries to remember as long a phrase as possible. The reader can look at the book for as long as is necessary. Then, when ready, she/he looks at the listener and says the phrase. While she/ he speaks, she/he does not look at the book. These rules force the reader to rely on memory. To analyze the data gained from post-test for both control and experimental class, the researcher used the t-test formula. The findings showed that $\mathrm{t}$-value higher than $\mathrm{t}$-critical, 1,671 $<5.8>2,390$ which means that Null Hypothesis (Ho) was rejected. Thus, it can be concluded that it is effective to use look up technique in teaching English speaking, because the research hypothesis (H1) which says "there is a difference in speaking skill between students who were taught using look-up technique and those who were taught using conventional technique (role-play) in their speaking class" was accepted.
\end{abstract}

Keywords: look-up technique, form-focused learning, meaning-focused input, fluency

Speaking as one of the four language skills is considerably visible skill. Common people may judge a learner has ability in English when he/she can speak English fluently (Ur, 1997:120). In recent years speaking usually meant 'repeating after the teacher, reciting a memorized dialogue, or repetition of drills' (Shrum \& Glisan, 2000: 26).

Research findings related to L2 speaking oral repetition and imitation-based practice has been widely used as one of the major methods to improve speech fluency in second language (L2) learning. Such rehearsal is used to enhance the familiarity of novel words, phrases, and sentences with an em- phasis on intonation and speed. Studies of individual differences in language learning have shown that it is important to maintain and rehearse phonological information in working memory. It is generally believed that learners have more problems with sentence production when a sentence contains novel words or unfamiliar phrases. Considering the fact that novel information increases cognitive loads in working memory, language fluency is more likely to be interrupted when L2 learners have to process new words.

Studies showed that lack exposure to a target language affected the success of language development at the acquiring stages (Brown, 
2001; Koverman et al, 2008). As Maxom (2009) identified, elementary level-typed students interact with their occupied vocabularies of which they learn to use many more verbs besides to be (I am, you are, it is). The students learn to talk and ask about matters related to daily routines. They also begin to refer to past and future time while at pre-intermediate level, students learn to discuss their experiences and future plans. They learn vocabulary related to their daily life and are able to discuss leisure activities and explain their preferences.

Brown (2001) suggests principles for designing speaking techniques supported by meaning-focused input as follows: 1) the techniques used cover the spectrum of learner needs, from language-based focus on accuracy to message-based focus on interaction, meaning, and fluency, 2) the techniques should be intrinsically motivating, 3 ) the use of authentic language is encouraged in meaningful context, 4) appropriate feedback and correction must be available, 5) speaking and listening, reading and writing must be naturally linked, 6) opportunities to initiate oral communication should be wide open, 7) development of speaking strategies is encouraged.

However, in the classroom, it is difficult for a teacher to pay attention to individual students to point out errors in their speech. Some learners are able to repeat a model sentence at the same speed immediately, while others may pretend that they are done with the repetition when the classroom becomes silent. Individual differences may vary even more with increases in the number of novel vocabulary items in a sentence. Practice can reduce these disfluencies.

No study has looked at the possible relation of simple oral repetition with fluency in L2 speech. The current study looked at the effect of look-up technique in rehearsing sentences that involved novel vocabulary. Lookup technique is the technique that applies speaking oral repetition and imitation-based practice using sentences that have been seen at a glance. Do the students receiving a lookup technique treatment demonstrate better speaking skills achievement compared to the group who are given another conventional technique?

West (1941) said that look-up technique is the most valuable from all methods of learning a language. It seems effective to improve learners' speaking ability and the development of their speaking skills. Abied (2011) found that this technique is proven to be able to improve the students' reading ability.

Unlike Abied's research, which focuses on the use look-up technique to increase students' reading skill, the present study is specified on the improvement of speaking skills. The researcher believed that the technique could improve the students' speaking skill because actually the look-up has reading input and spoken output (Nation, Paul: 1991). Therefore, the researcher referred some characteristics of successful speaking activity as pointed out Burns and Joyce (1997). Students can use grammar structures accurately in their speaking. Diction is understandable and suitable for the topic discussed. Students using gesture or body language while expressing their ideas. Students talk a lot in a period allocated by teacher.

\section{METHOD}

The research design was quasi-experimental since it is considerably practical in the classes where the researcher had no access to the arrangement of the sample $(\mathrm{Nu}-$ nan, 1992). Stratified purposive sampling is chosen both from experiment class and control class to maintain equality of the expected subjects and minimize bias (Ary, et al., 2006). Two existed classes nonrandomized groups here are already existed classes. Pretest and posttest help in determining whether any difference exists or not. This is to see whether the treatment has changed the score from the 
pretest to the posttest (Lodico, et al., 2006). This research is taken in STAIN Palangkaraya at Jalan G.Obos kompleks Islamic Centre Palangkaraya, Central Kalimantan, on January 28th to April 19th 2012.

Population and Sampling

The population of this research is the students of second semester in State Islamic College (STAIN) Palangkaraya. The researcher took two out of three classes $(\mathrm{A}, \mathrm{B}$, and C classes) randomly and the total number was 74 students. The B class consisted of 37 students was given the treatment by using lookup technique while the $C$ class consisted of 37 students applied another conventional technique. The instruments used are speaking test; pre-test and post-test. It was used as the researcher consideration in deciding the criteria of success. The pre-test is to check the similarity level of the two groups and the post-test is used to measure the progress of the study. The researcher used scoring guide developed by Folse (2006). There are four criteria in testing speaking which are pronunciation, fluency, grammar, and vocabulary (Syakur, 1987:3).

Try out test was conducted on 28 January 2012 at A class. There were 31 students came to the try out session and were divided into two groups. The first group was 15 students and the second was 16 students. The pre-test was tried out to 15 students (Group 1) while the post-test was tried out to 16 students (Group 2). There are two raters (testers) that measure the speaking skill ability in pre- and post tests. The first rater is the teacher that implement look-up technique and another independent English teacher but still from STAIN Palangkaraya. The first rater is a 33 years-old male. The second rater is a 35 years-old male. The validity of the instruments is assured by content validity evidence and scoring validity evidence.

\section{FINDINGS}

There were two classes in the same semes- ter that was used for this research. Class B was assigned to be the experimental class and class $C$ was assigned to be the control class. The score was taken from two raters and each rater took the score from four elements to measure: grammar, vocabulary, fluency, and pronunciation. Seen from the pre-test scores, the two classes were in two different levels.

Table 1: The Summary of t-test Computation for Pre-test Result

\begin{tabular}{ll}
\hline Experimental Group & Control Group \\
\hline $\mathrm{N} 1=37$ & $\mathrm{~N} 2=37$ \\
$\sum X_{1}=2096$ & $\sum X_{2}=2012$ \\
$\sum X_{1}{ }^{2}=119266$ & $\sum X_{2}^{2}=109772$ \\
$\bar{X} \quad$ & $\bar{X}=54,38$ \\
$1=56,65$ & $2=3,1$ \\
$\mathrm{~S} 1=3,765$ & $\mathrm{~S} 2=5$ \\
\hline
\end{tabular}

From the summary above, it showed that the result of the test from two groups has little difference. It could be seen from the mean score which was got. The researcher also finds standard error of the difference between means formula to find the $t$-value.

The result of standard error $\left(S D_{\bar{X}} S D_{\bar{X}}\right)$ of the difference between means for pre-test was 0,812 (see appendix 6 for detail). To complete the result of the research, the researcher finds out $t$-value. The result of $t$-value was 2,790 . Meanwhile, the result of critical values of $t$ based on formula DF $=(\mathrm{N} 1+\mathrm{N} 2)-2$ was 72 .

At the degree of significance $5 \%=1,671$

At the degree of significance $1 \%=2,390$

The result was $1,671<2,790>2,390$

The result of analyzing the data by using the above formula shows that the coefficient was 2,790 . It means that there was difference significant of the speaking skill between experimental and control group.

The researcher gave the treatment eight times for the experimental group before postest was given. The result of post-test from the experimental and control group will be showed as the table: 
Table 2: The Summary of t-test Computation for Post-test Result

\begin{tabular}{ll}
\hline Experimental Group & Control Group \\
\hline $\mathrm{N} 1=37$ & $\mathrm{~N} 2=37$ \\
$\sum X_{1}=2601$ & $\sum X_{2}=2405$ \\
$\sum X_{1}^{2}$ & $\sum X_{2}{ }^{2}$ \\
$\bar{X}=183219$ & \\
$1=70,3$ & $\bar{X}=157065$ \\
$\mathrm{~S} 1=3,13$ & $2=65$ \\
\hline
\end{tabular}

From the table above, it could be found that the result of the test from two groups have a little difference. It could be seen from the mean score which was got. The researcher used same formulas in pre-test while finding standard error, $t$-value and critical values. The standard error was 0,91 and the $t$-value was 5,8 .

At the degree of significance $5 \%=1,671$

At the degree of significance $1 \%=2,390$

The result was $1,671<5,8>2,390$

The result of analyzing the data by using the above formula shows that the t-test coefficient was 5,8. It means that there was a significant increase after the look-up technique was used to teach speaking. Having analyzed the data of post-test by using t-test formula, the result shows that the coefficient is 5,8 . It means that there is a significance increase in teaching speaking by using look-up technique. From the result of post-test calculation, shows that $\mathrm{t}$-value higher than $\mathrm{t}$-critical, $1,671<5,8>2,390$ which means that Ho was rejected. Thus, the research hypothesis (H1) which says "there is a difference in speaking skill between students who were taught using look-up technique and those who were taught using role-play in their speaking class" was accepted.

Referring to the parameter estimates on test after treatment, it was evident that if a student uses look-up technique in learning speaking, his or her speaking skill score will be 5,8 higher than the one who uses role play technique. Look-up technique has effects on students' ability in speaking (see appendix 7 for the calculation).

Based on the result of the data analysis, it is proven that students' score of speaking taught by using look-up technique is better. It means that the use of look-up technique in teaching speaking is quite effective. Another reason based on the student responses is because most students find that the technique is enjoyable. This reason leads to better attention in learning and stimulate them to participate in dialogue activities.

However, the problem that they faced mostly is lack of confidence and lack of vocabulary. In the early stages of the look-up technique the students were uncomfortable and uncertain. This led to initial lapses of silence. But soon they began helping one another to decide who should speak within pair conversation. Towards the end, their shyness left them and they began prompting each other mastering speaking English.

\section{DISCUSSION}

The research findings show that students practiced the look-up technique scored better speaking results than those of the control class. It indicated that this strategy give significant effects to the experimented subjects. This result validates what Nation and Newton's findings that teaching speaking can focus on form and meaning respectively (Nation \& Newton, 2007). Interestingly, some low proficient students increased their speaking skills through a series of activity. Contextual repetition and expressive practice made vocabularies and grammar patterns possibly internalized. Repetition on conversational aspects help students practiced expressions they use for communication. Moreover, intensive speaking practice enhanced their ability in order to get understanding plugged in mind. Look-up technique not only helped students understand certain aspects of spoken language, this strategy also raised grammatical and phonological awareness through 
frequent sentence drills in communicative interaction. This implies an important function of communicative competence in communication, meaning that speaking competence has an important role in the development of communicative competence.

However, this research contained limitations to be interpreted. Class control and experimental class experienced a similar situation. There were numbers of subjects who were full of enthusiasm of learning as well as less motivated subjects. It missed to discuss the degree of enthusiasm and motivation of learning as another contributing variable that appears to weaken its results.

In the control class, subjects with strong motivation showed competitive scores. They were active in speaking practices and responded to teacher's remarks and opinion. They performed in most activities enthusiastically as well as motivated students in the experimental class. In the experimental group, subjects were actually less likely to use other language strategies. Especially when they knew that other class did not have the same instruction. Different treatment was sufficient evidence that bother those, especially, the low motivated students. Motivation has become uncontrolled variable in this study.

In general, contextualization in the teaching of speaking had a positive impact on more able students. On those who lack the language ability it was tedious. Teacher / researcher should adapt in the best possible circumstances. At the exercising stage, the able students looked more active and focused. Here they could verify their current understanding in the stage of contextualization. Enthusiasm of the students appeared when free oral practices were given. As part of look-up strategy, this stage provided students with opportunities to express their thoughts. Students seemed to have weapons to communicate freely in spoken form.

The topics spoken in the free conversation especially were about the story of their daily lives. The use of simple tenses, nouns, adjectives, adverbs packed in simple sentences explained this fact. The difference lied in the different mean of the scores where the subjects in experimental group outnumbered the results of those in control class.

\section{CONCLUSION}

Based on the result of data analysis using t-test, it is concluded that applying look-up technique has positive effect on students' speaking skills. Students who experience look-up technique tend to communicate accurately as reflected on their overall results. The result of post-test calculation shows that t-value higher than $\mathrm{t}$-critical, 1,671 $<5,8>2,390$ which means that Null Hypothesis (Ho) was rejected. Thus, the research hypothesis (H1) which says "there is a difference in speaking skill between students who were taught using look-up technique and those who were taught using conventional technique (roleplay) in their speaking class" was accepted. Therefore, it can be concluded that look-up technique is relatively more effective than conventional teaching speaking activity. The researcher presents recommendations for future researchers and English teacher/ instructors as follow: first, while the finding of this research suggest that look-up technique played relatively significant role in improving the experimented students' speaking skills, it would be beneficial to conduct another follow-up research to further validate the effectiveness of look-up technique on EFL/ESL students' speaking skills. 


\section{REFERENCES}

Abied. (2011). The Effectiveness of Lookup Technique to Improve Reading Skills of SMAN 5 Surabaya. Unpublished Thesis. Surabaya: State University of Surabaya.

Ary, D., Jacobs, Cheser, L., Razavieh, A. \& Sorensen, C. (2006). Introduction to Research in Education (7th ed.). Belmont: Thomson Wadsworth.

Brown, H. D. (2001). Teaching by Principles: An Interactive Approach to Language Pedagogy (2nd ed.). New York: Pearson Education.

Brown, H. D. (2004). Language Assessment. White Plains: Addison Wesley Longman Inc.

Burns, A., \& Joyce, H. (1997). Focus on Speaking. Sydney: Macquarie University Press.

Burns, A., \& Joyce, H. (1999). Focus on grammar. Sydney: National Centre for English Language Teaching and Research.

Cahyono, B. Y. (1997). Pengajaran Bahasa Inggris: Teknik, Strategi, dan Hasil Penelitian. Malang: IKIP Malang.

Cohen, L., Manion, L., \& Morrison, K. (2005). Research Methods in Education (5th ed.). London: Routledge Falmer \& Taylor \& Francis Group.

Cushman, D.P. \& King, S.S.(1997). Communication and High-Speed Management. New York: State University of New York Press.

Curtis, D. B., Winsor, J. L.,\& Stephens, R. D.(1989). National Preferences in Business and Communication Education.38 (2): 6-14. Cambridge: Cambridge University Press.

Folse, K. S. (2006). The Art of Teaching Speaking: Research and Pedagogy for the ESL/ EFL Classroom. Ann Arbor: The University of Michigan Press.

Fulcher, G., \& Davidson, F. (2007). Language Testing and Assessment: an advanced resource book. New York: Routledge.

Harmer, J. (2007). The Practice of English Language Teaching (4th ed.). Essex: Pearson Education.

Koverman et al. (2008). Testing for Language Teachers. Cambridge: Cambridge University Press.
Hughes, R. (2002). Teaching and Researching Speaking. Essex: Pearson Education.

Kayi, H. (2006). Teaching Speaking: Activities to Promote Speaking in a Second Language. The Internet TESL Journal, Vol. XII, No. 11 (http://iteslj.org/ accessed on Desember 12th 2008)

Lodico, M.G., Spaulding, D.T., \& Voegtle, K.H. (2006). Method in educational research: From theory to practice. San Francisco, CA: Jossey Bass

Lucantoni. (2002). Language Teaching Analysis. Bloomington: Indiana University Press.

Mackey, W. (1967). Language Teaching Analysis. Bloomington: Indiana University Press.

Mason, E.J. \& Bramble, W.J. (1989). Understanding and Conducting Research (2nd ed.). New York: St. Louis et al: McGrow-Hill Book Company.

Maxom. (2009). Research Methods in Language Learning. New York: Cambridge University Press.

Nation, I. S. P., \& Newton, J. (2009). Teaching ESL/EFL Listening and Speaking. New York: Routledge.

Nation, I.S.P.(1991).Dictation, dicto-comp and related techniques. English Teaching Forum 29, 4, : 12-14.

Nunan, D. (1991). Second Language Teaching and Learning. Boston: Heinle \& Heinle Publishers.

Nunan, D. (1992). Research Methods in Language Learning.Cambridge: CUP

Nunan, D. (2003). Practical English Language Teaching. New York: McGraw-Hill.

Sarwoko, T.A. (2007). Statistik Inferensi Untuk Ekonomi Dan Bisnis, Yogyakarta: ANDI

Shrum, J. L. \& Glisan, E. W. (2000).Teacher's Handbook: Contextualized Language Instruction, (2nd ed.). Boston: Heinle

Syakur. (1987). Language Testing and Evaluation. Surakarta: Sebelas Maret University Press.

Thornbury, S. (2005). How to Teach Speaking. Essex: Pearson Education Ltd. 
Ur, P. (2000). A Course in Language Teaching: Practice and Theory. Cambridge: Cambridge University Press.

Ur, P.(1997). The English teacher as profes- sional: English Teaching Professional 1(2), 3-5.

West, M. P. (1941). Learning to Read a Foreign Language. London:Longman. 
52 | Journal on English as a Foreign Language, Volume 2, Number 2, September 2012 